\title{
SEASONAL VARIATION IN THE DIVERSITY OF FLOWERING ORCHIDS AT Santa Catarina lachatao, OAXaca, Mexico
}

\section{VARIACIÓN ESTACIONAL EN LA DIVERSIDAD DE ORQUÍDEAS EN FLORACIÓN EN Santa Catarina lachatao, OAXaca, MÉXICO}

\author{
Arelee Estefanía Muñoz-Hernández 1 , @Dulce María Figueroa-Castro ${ }^{1 *}$, Álvaro Campos-Villanueva \\ ${ }^{1}$ Facultad de Ciencias Biológicas, Benemérita Universidad Autónoma de Puebla, México. \\ Estación de Biología Tropical Los Tuxtlas, Instituto de Biología, Universidad Nacional Autónoma de México, Veracruz, México
}

${ }^{*}$ Corresponding author: figgery@gmail.com

\begin{abstract}
Background: Orchidaceae represents around 7.1-8.52 \% of the angiosperms known in the planet. In Mexico, orchids are the third family more diverse, and Oaxaca is the state with the highest richness in the country. Orchids are widely distributed in tropical environments, but they are also distributed in temperate forests, where they have been scarcely studied.

Questions: What is the diversity of orchid species at the locality of Santa Catarina Lachatao? Which subfamilies and growth forms are distributed at that locality? Do the community of orchids flowers differentially between seasons?

Studied species: Species of the Orchidaceae family.

Study site and dates: Santa Catarina Lachatao, Oaxaca, 2017-2018.

Methods: Orchids were collected monthly throughout a year. Collected specimens were identified. Richness, abundance and diversity index were estimated for the whole flowering community, and per subfamily and growth form. These parameters were compared between seasons.

Results: The community of orchids was composed by 4,933 flowering individuals from 74 species from the subfamilies Epidendroideae and Orchidoideae. Orchids with terrestrial, epiphyte, and rupicolous growth forms were collected. Total diversity index and species composition varied between seasons. Seasonal variation in abundance, diversity and species composition per subfamily and per growth form was also detected.

Conclusions: Orchid diversity at the locality is high $(9.68 \%$ of the richness recorded for Oaxaca), and varies between seasons. The high species richness, the endemisms and endangered species found, call to take prompt actions to protect and manage the forest to assure its conservation and the diversity within it.
\end{abstract}

Keywords: Epidendroideae, growth form, Orchidoideae, Shannon diversity index, species composition, species richness.

\section{Resumen}

Antecedentes: La familia Orchidaceae representa el 7.1-8.52 \% de las angiospermas del planeta. En México, ésta es la tercera familia más diversa, y Oaxaca registra la mayor riqueza. Orchidaceae se distribuye ampliamente en ambientes cálidos, pero también en bosques templados, donde han sido menos estudiada.

Preguntas: ¿Cuál es la diversidad de especies de orquídeas en Santa Catarina Lachatao? ¿Qué subfamilias y formas de vida se distribuyen en la localidad? ¿La floración de la comunidad de orquídeas es distinta entre estaciones?

Especies de estudio: Especies de la familia Orchidaceae.

Sitio y años de estudio: Santa Catarina Lachatao, Oaxaca, 2017-2018.

Métodos: Se colectaron e identificaron las orquídeas en floración durante un año. La riqueza, abundancia e índice de diversidad de orquídeas en floración fueron estimados para la comunidad completa, así como por subfamilia y forma de vida. Se compararon estos parámetros entre estaciones.

Resultados: Se registraron 4,933 individuos en floración de 74 especies de las subfamilias Epidendroideae y Orchidoideae. Se colectaron orquídeas con forma de vida terrestre, epífita y rupícola. La diversidad y la composición de especies de toda la comunidad difirieron entre estaciones. La abundancia, la diversidad y la composición de especies por subfamilia y por forma de crecimiento también variaron entre estaciones.

Conclusiones: La diversidad de orquídeas de la localidad es alta (9.68 \% de la reportada para Oaxaca) y variable entre estaciones. La alta riqueza específica, el número de endemismos y de especies amenazadas encontradas urgen a tomar acciones para proteger el bosque y la biodiversidad que lo compone.

Palabras clave: Composición de especies, Epidendroideae, forma de crecimiento, índice de diversidad de Shannon, Orchidoideae, riqueza de especies. 
The Orchidaceae family constitutes around 7.1-8.52\% (Stevens 2001 onwards) of the flowering plants known (Roberts \& Dixon 2008). Approximately, between 25,000 to 30,000 orchid species from 700-850 genera have been described around the globe (Chase et al. 2003). Plants from this family are classified within five subfamilies, Cypripedioideae, Vanilloideae, Epidendroideae, Orchidoideae, and Apostasioideae (Cribb et al. 2003, Hágsater et al. 2005). Orchids are widely distributed around the globe, except those from the Apostasioideae subfamily, whose distribution is limited to the Southeast Asia and Oceania (Pridgeon et al. 1999, Hágsater et al. 2005, TéllezVelasco 2011).

Depending on the substrate on which orchids grow, three different growth forms have been described (WilliamsLinera et al. 1995, Hágsater et al. 2005, Swarts \& Dixon 2009a, Zhang et al. 2015). Orchids growing on soil are called terrestrial; those that develop on other plants are known as epiphytes, and those that use rocks as its substrate are rupicolous (Williams-Linera et al. 1995, Hágsater et al. 2005, Swarts \& Dixon 2009a, Zhang et al. 2015). Out of the total number of species within the family, those with terrestrial growth form constitute $27-33 \%$; whereas the remaining $66-73 \%$ corresponds to the rupicolous and epiphyte orchids together (Roberts \& Dixon 2008, Santa et al. 2009, Swarts \& Dixon 2009a).

In Mexico, the Orchidaceae family is represented by around 1,260 species from 170 genera (Hágsater et al. 2005, Soto-Arenas et al. 2007a). Epidendroideae is the richest subfamily with around $80 \%$ of the species described in the country (Hágsater et al. 2005). Epiphyte orchids are the most representative in Mexico, with $83 \%$ of the species known (Noguera-Savelli \& Cetzal-Ix 2014). Orchids are widely distributed in the south portion of the country (Rzedowski 1996). Cloud forests and rainforests are among the ecosystems with the highest species richness of orchids, accounting for $70-90 \%$ of the known species (Espejo-Serna et al. 2005, Cox et al. 2016). Within Mexico, Oaxaca has the highest diversity of orchids, with around 733 species from the subfamilies Epidendroideae (583 species), Orchidoideae (99), Vanilloideae (7), and Cypripedioideae (3; Soto-Arenas \& Salazar 2004, Solano-Gómez et al. 2016). However, the richness of orchid species in Oaxaca might be much higher since only around $20 \%$ of its territory has been explored floristically (García-Mendoza 2004).

Although orchids are distributed in all ecosystems, most studies on the floristic diversity of this family of plants have been conducted in rainforests and cloud forests (MejíaRosero \& Pino-Benítez 2009, Focho et al. 2010, Allesh et al. 2011, García-González \& Pérez-Márquez 2011, Gogoi et al. 2012a, $\underline{\mathrm{b}}$, Morales 2012, Gutiérrez 2014, Damian 2015, Nurfadilah 2015, Susan-Tepetlan et al. 2015, Castillo-
Hernández \& Flores-Olvera 2017, Tejeda-Sartorius \& Tellez-Velasco 2017). In contrast, fewer studies on floristic diversity of orchids have been conducted in temperate habitats (Cerros-Tlatilpa \& Espejo-Serna 1998, Calatayud 2005, Luna-Rosales et al. 2007, Huang et al. 2008, Rewicz et al. 2015). In Mexico, temperate forests cover $21 \%$ of its territory (Rzedowski 1992) and, in the Oaxaca state this type of vegetation covers around $33,636 \mathrm{~km}^{2}$, which corresponds to $35 \%$ of its territory (González-Ríos 2011). Even so, fewer studies on the diversity of orchids in temperate forests of Oaxaca have been conducted (Santiago 2018). Moreover, most studies on orchid diversity are floristic, and do not describe how seasonality might define the flowering period of different orchids, nor offer an ecological analysis by growth form. The goal of this study was to determine the diversity of orchids in the locality of Santa Catarina Lachatao, within the Sierra Norte (Northern Mountain Range), Oaxaca state, Mexico. Particularly, we were interested in describing and comparing the parameters of the community (i.e., species richness, abundance, diversity and composition) between seasons. In addition we analyzed those same parameters at the subfamily level and by growth form.

\section{Materials and methods}

Study site. The study was conducted at the locality of Santa Catarina Lachatao, in the State of Oaxaca, South of Mexico $\left(17^{\circ} 05^{\prime}-17^{\circ} 17^{\prime} \mathrm{N}, 96^{\circ} 27^{\prime}-96^{\circ} 33^{\prime} \mathrm{W} ; 1,800-3,200 \mathrm{~m}\right.$ asl; INEGI 2005). Vegetation at the locality is a temperate forest dominated by Pinus and Quercus species (UMAFOR 2007). In addition, some components of cloud forest such as Alnus acuminata, Arbutus jalapensis, Dendropanax sp., Drymis granadensis and Prunus sp. are also found. Climate is temperate, semi-cold, sub-humid, with a strong seasonality in which a rainy season from May to October and a dry one from April to November are distinguished (INEGI 2005, UMAFOR 2007). Mean temperature at the locality varies from 12 to $20{ }^{\circ} \mathrm{C}$, whereas precipitation varies from 800 to $1,200 \mathrm{~mm}$ (INEGI 2005, UMAFOR 2007).

The study was conducted at the locality of Santa Catarina Lachatao for several reasons. First, the locality belongs to the Oaxaca state which has the highest orchid species richness in the country (Soto-Arenas \& Salazar 2004, Solano-Gómez et al. 2016), but from which only $20 \%$ of its territory has been explored (García-Mendoza 2004). Second, most studies on orchid diversity have been conducted in rainforests and cloud forests (Mejía-Rosero \& Pino-Benítez 2009, Focho et al. 2010, Allesh et al. 2011, García-González \& Pérez-Márquez 2011, Gogoi et al. 2012a, b, Morales 2012, Gutiérrez 2014, Damian 2015, Nurfadilah 2015, Susan-Tepetlan et al. 2015, Castillo- 
Hernández \& Flores-Olvera 2017, Tejeda-Sartorius \& Tellez-Velasco 2017); thus, there is a lack of studies addressing the diversity of orchids at temperate forests such as the one found in Santa Catarina Lachatao. Third, the locality is found within the Sierra Norte of the Oaxaca state where the main economic activity is the forestry (Santiago 2018). Within the region, Santa Catarina Lachatao is one of the few towns that does not conduct that kind of forest practices (Rojas-Serrano \& Martínez-Corona 2017, J. Santiago-Hernández, pers. comm.). Finally, people at Santa Catarina Lachatao are very conscious of the importance of conserving the forest to assure the provision of water and other profits (wood, mushrooms, medicinal plants); and their own wellness (Rojas-Serrano \& Martínez-Corona 2017).

The community of orchids. In order to describe the ecological parameters of the orchid community at the locality of study, we conducted 12 monthly field trips from July 2017 to June 2018. In each field trip we collected specimens of all flowering orchids on a trip of around $24 \mathrm{~km}$ that covered an area of $900 \mathrm{ha}$. Such distance was covered by foot in two consecutive days each month, through both tracking roads as well as cross country. Orchids were collected from soil, rocks and trees (up to $4 \mathrm{~m}$ in height), and the number of individuals of each species was counted. A maximum of three individuals from each orchid species was collected. All collected orchids were herborized using standard methods and identified to the lowest taxonomic level using Soto-Arenas et al. (2007b), and Espejo-Serna et al. (2002). Specimen identification was confirmed by the orchid specialists Gerardo A. SalazarChávez and Rolando Jiménez-Machorro. Orchid specimens were deposited at the Herbario Nacional de México (MEXU).

Species richness, abundance, and Shannon-Wiener diversity index were estimated, and the composition of the whole community of orchids was determined. Likewise, those same parameters were estimated for the groups of orchids flowering at each season of the year (rainy: May October; dry: November -April), per subfamily and per growth form (terrestrial, epiphyte, rupicolous, and orchid species whose individuals might growth in two growth forms). Comparisons of the parameters of the subcommunities of flowering orchids between seasons and subfamilies as well as among growth forms were conducted using: i) $\chi^{2}$ tests for species richness and abundance, ii) $t$-Hutcheson for the diversity index and iii) the Sörensen similarity index for species composition. All analyses were conducted in PAST 3.09 (Hammer et al. 2001).

\section{Results}

The orchid community. The community of orchids at the locality of study was composed by 4,933 flowering individuals from 74 species, 39 genera and two subfamilies:
Epidendroideae (49 species), and Orchidoideae (25 species; Table 1). The richest genera were Epidendrum, and Prosthechea (six species each), followed by Bletia (5 species), and Oncidium (4 species). Orchids from the three growth forms described in the family were collected: 32 species were terrestrial, 24 epiphyte, and 13 rupicolous. In addition, five species had two growth forms: Prosthechea michuacana (La Llave \& Lex.) W.E. Higgins, P. varicosa (Bateman) W.E. Higgins (Epidendroideae) and Deiregyne eriophora (B.L. Rob. \& Greenm.) Garay (Orchidoideae) were observed growing on soil (i.e. terrestrial) as well as on other plants (i.e. epiphytes). Prosthechea semiaperta (Hágsater) W.E. Higgings (Epidendroideae) was observed as rupicolous and epiphyte, whereas Ponthieva mexicana (A. Rich. \& Galeotti) Salazar (Orchidoideae) showed terrestrial and rupicolous growth forms (Table 1). Out of the 74 species identified, seven species or subspecies $(9.5 \%)$ were endemic to the State of Oaxaca (Figure 1; Soto-Arenas \& Salazar 2004): Anathallis oblanceolata (L. O. Williams) Solano \& Soto Arenas, Barkeria melanocaulon A. Rich. \& Galeotti, Epidendrum costatum A. Rich. \& Galeotti, E. juergensenii Rchb. f., Isochilus oaxacanus Salazar \& Soto Arenas, Laelia furfuracea Lindl., and Rhynchostele cervantesii subsp. membranacea (Lindl.) Soto Arenas \& Salazar (Epidendroideae). In addition, other 44 species $(59.5 \%)$ were endemic from Mexico (Table 1; Enciclovida 2019).

Seasonal variation on the communities of flowering orchids. During the dry and rainy seasons, the community of flowering orchids was constituted by 2,460 and 2,473 individuals from 50 and 45 species, respectively. Species richness $\left(\chi_{1}^{2}=0.263, P=0.607\right.$; Figure 2A), and orchid abundance $\left(\chi_{1}^{2}=0.034, P=0.85\right.$; Figure 2B $)$ did not differ between seasons. In contrast, the diversity index was significantly higher during the dry season $\left(\mathrm{H}^{\prime}=2.94\right)$ in comparison with the rainy one $\left(\mathrm{H}^{\prime}=2.41 ; t_{4925.2}=14.02\right.$, $P<<0.0001$; Figure 2C). Out of the 74 species collected, only 21 flowered in both seasons (Sörensen similarity index $=44.21 \%$; Table 1), some of them are Anathallis oblanceolata, Maxillaria cucullata Lindl., Oncidium graminifolium Lindl. (Epidendroideae), and Galeoglossum tubulosum (Lindl.) Salazar \& Soto Arenas (Orchidoideae). In contrast, 29 and 24 species flowered exclusively during the dry and rainy seasons, respectively (Table 1). For instance, Deiregyne eriophora (Orchidoideae) and Prosthechea michuacana (Epidendroideae) flowered only during the dry season, whereas Stelis veracrucencis Solano (Epidendroideae) did it during the rainy one.

Analysis at the subfamily level. A total of 1,581 flowering individuals from 36 species of the Epidendroideae subfamily flowered during the dry season; whereas 

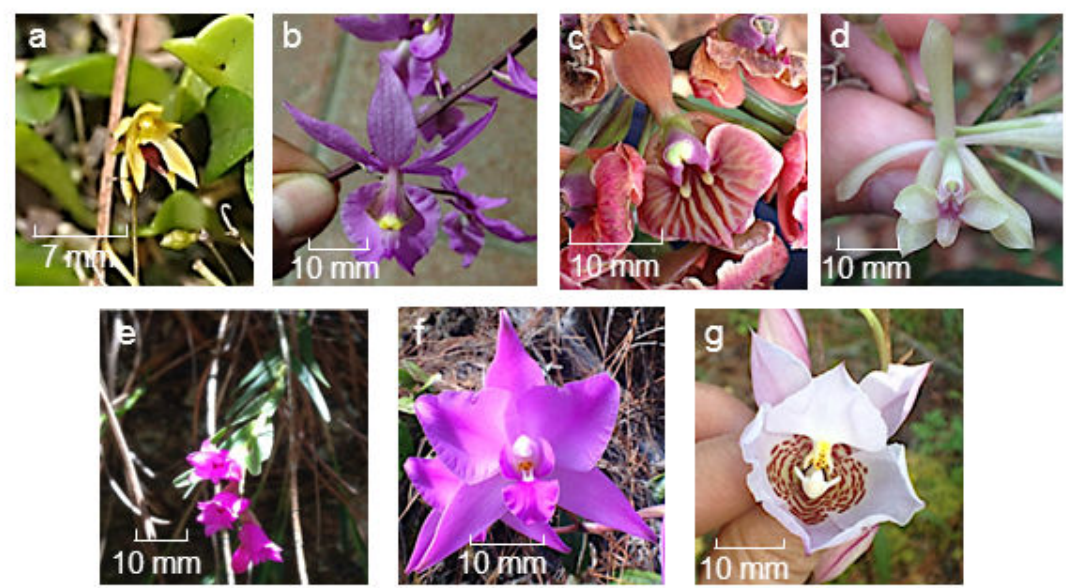

Figure 1. Endemic orchid species to the state of Oaxaca collected at the locality of study. a) Anathallis oblanceolata (Epidendroideae), threatened species according with the NOM-059 (SEMARNAT $2010 \mathrm{a}$, b); b) Barkeria melanocaulon (Epidendroideae), threatened species according with the NOM-059 (SEMARNAT 2010 a , b); c) Epidendrum costatum (Epidendroideae); d) E. juergensenii (Epidendroideae); e) Isochilus oaxacanus (Epidendroideae); f) Laelia furfuracea (Epidendroideae), subjected to special protection according with the NOM-059 (SEMARNAT $2010 \mathrm{a}$, b); and, g) Rhynchostele cervantesii subsp. membranacea (Epidendroideae), threatened species according with the NOM-059 (SEMARNAT $2010 \mathrm{a}, \underline{b})$.

1,860 individuals belonging to 15 species flowered during the rainy one. Epidendroideae species richness did not differ significantly between seasons $\left(\chi_{1}^{2}=0.37, P=0.54\right.$; Figure $3 \mathrm{~A})$. In contrast, abundance of flowering species of Epidendroideae was significantly higher during the rainy season in comparison with the dry one $\left(\chi_{1}^{2}=22.62\right.$, $P<<0.001$; Figure 3B), whereas the opposite pattern was observed for diversity $\left(t_{3174.8}=27.185, P<0.0001\right.$; Figure $3 \mathrm{C})$. Epidendroideae diversity index during the dry season was $\mathrm{H}^{\prime}=3.05$, whereas during the rainy one it was $\mathrm{H}^{\prime}=1.97$. Similarity index between seasons for flowering orchids within this subfamily was $53.73 \%$. Out of the 49 Epidendroideae species recorded, 18 flowered in both seasons (Table 1). In contrast, 18 and 13 species flowered exclusively on the dry and rainy seasons, respectively (Table 1).

A similar number of orchids from the Orchidoideae subfamily were observed flowering at each season (14 species; $\chi^{2}{ }_{1}=0.0, P=1.0$; Figure $3 \mathrm{~A}$ ). Both abundance and diversity index were significantly different between seasons. A total of 879 and 613 Orchidoideae individuals flowered during the dry and rainy seasons, respectively $\left(\chi_{1}^{2}=47.4, P<<0.001\right.$; Figure 3B $)$. Diversity index was significantly higher during the rainy season $\left(\mathrm{H}^{\prime}=1.48\right)$ in comparison with the dry one $\left(\mathrm{H}^{\prime}=0.94 ; t_{1458.4}=8.26\right.$, $P<<0.001$; Figure 3C). Similarity index of flowering orchids within Orchidoideae was $21.42 \%$; only Cyclopogon Presl. sp. 1, Cyclopogon sp. 2, and Galeoglossum tubulosum flowered in both seasons. In contrast, 11 species flowered exclusively on each season (Table 1).

Analysis per growth form. Flowering species richness varied across growth forms and seasons. Nine and 21 epiphytes,
24 and 15 terrestrial, 9 and 10 rupicolous as well as 3 and 5 species with two growth forms were recorded flowering during the rainy and dry seasons, respectively. However, we did not find a significant association between season and growth form for species richness $\left(\chi_{3}^{2}=6.56, P=0.09\right.$; Figure 4A). In contrast, a significant association between season and abundance of flowering orchids across growth forms was detected $\left(\chi_{3}^{2}=1921.2, P<<0.0001\right.$; Figure 4B). An abundance of 1,367 and 238 rupicolous individuals, 241 and 808 epiphytes, 791 and 473 terrestrial; as well as 74 and 941 individual orchids with two growth forms flowered during the rainy and dry seasons, respectively (Figure 4B).

Diversity index of flowering orchids varied between seasons depending upon growth form (Figure 4C). Epiphyte and rupicolous orchids had significantly higher diversity index (epiphyte: $t_{339.27}=16.1, P<0.0001$; rupicolous: $\left.t_{319.18}=8.96, P<<0.0001\right)$ during the dry season $(2.43$ and 1.71 , respectively) in comparison with the rainy one (1.2 and 1.06, respectively). In contrast, diversity index of terrestrial (dry: 2.18 , rainy: $2.04 ; t_{1223.5}=2.32, P=0.2$ ) and two-growth forms orchids (dry: 0.75, rainy: 0.835; $t_{108.76}=1.38, P=0.17$ ) did not vary between seasons.

The composition of flowering orchid species varied between seasons for all growth forms. Terrestrial flowering orchids had the lowest similarity index (35.9\%) between seasons; only seven out of the 32 species with this growth form flowered in both seasons. Similarity index of flowering epiphytes was $40 \%$; only six species out of the 24 orchids with this growth form flowered on both seasons. The composition of flowering rupicolous and two-growth forms orchids were relatively more similar between seasons ( $\mathrm{S}=63.2 \%$ and $57.1 \%$, respectively); six and two species, respectively, flowered on both seasons (Table 1). 
Table 1. Flowering orchid species collected during a year in the locality of Santa Catarina Lachatao, Oaxaca. Total abundance as well as number of individuals flowering during the dry (D) and rainy (R) seasons are provided. Growth forms (GF) are abbreviated as follows: $\mathrm{E}=$ epiphyte, $\mathrm{R}=$ rupicolous, $\mathrm{T}=$ terrestrial. * = endemic species to the State of Oaxaca (Soto-Arenas \& Salazar 2004), ** = endemic species to Mexico (Enciclovida 2019), $+=$ threatened species, $++=$ species subjected to special protection according with the NOM-059 (SEMARNAT 2010 a, $\underline{\text { b) }}$.

\begin{tabular}{|c|c|c|c|c|}
\hline \multirow{2}{*}{$\begin{array}{r}\text { Subfamily } \\
\text { Species }\end{array}$} & \multirow{2}{*}{ GF } & \multicolumn{2}{|c|}{ Season } & \multirow{2}{*}{ Total } \\
\hline & & $\mathbf{D}$ & $\mathbf{R}$ & \\
\hline \multicolumn{5}{|l|}{ Epidendroideae } \\
\hline Alamania punicea subsp. greenwoodiana Soto Arenas \& R Jiménez ** & $\mathrm{E}$ & 42 & 0 & 42 \\
\hline Anathallis oblanceolata (L.O. Williams) Solano \& Soto Arenas *,+ & $\mathrm{R}$ & 17 & 774 & 791 \\
\hline Arpophyllum spicatum Lex. ** & $\mathrm{R}$ & 3 & 16 & 19 \\
\hline Artorima erubescens (Lindl.) Dressler \& G.E. Pollard ** & $\mathrm{E}$ & 3 & 0 & 3 \\
\hline Barkeria melanocaulon A. Rich. \& Galeotti *,+ & $\mathrm{T}$ & 2 & 0 & 2 \\
\hline Bletia jucunda Linden \& Rchb. f. ** & $\mathrm{T}$ & 0 & 1 & 1 \\
\hline Bletia lilacina A. Rich. \& Galeotti ** & $\mathrm{T}$ & 5 & 6 & 11 \\
\hline Bletia neglecta Sosa ** & $\mathrm{T}$ & 0 & 1 & 1 \\
\hline Bletia purpurata A. Rich. \& Galeotti & $\mathrm{T}$ & 0 & 1 & 1 \\
\hline Bletia reflexa Lindl. ** & $\mathrm{T}$ & 0 & 8 & 8 \\
\hline Coelia macrostachya Lindl. & $\mathrm{R}$ & 0 & 40 & 40 \\
\hline Corallorhiza bulbosa A. Rich. \& Galeotti ** & $\mathrm{T}$ & 0 & 20 & 20 \\
\hline Corallorhiza odontorhiza var. pringlei (Greenm.) Freudenst. & $\mathrm{T}$ & 15 & 90 & 105 \\
\hline Dichaea glauca Lindl. ** & $\mathrm{T}$ & 38 & 0 & 38 \\
\hline Epidendrum costatum A. Rich. \& Galeotti $*$ & $\mathrm{E}$ & 0 & 2 & 2 \\
\hline Epidendrum juergensenii Rchb. f. * & $\mathrm{E}$ & 30 & 0 & 30 \\
\hline Epidendrum lignosum Lex. ** & $\mathrm{E}$ & 174 & 0 & 174 \\
\hline Epidendrum propinquum A. Rich. \& Galeotti ** & $\mathrm{R}$ & 0 & 48 & 48 \\
\hline Epidendrum radioferens (Ames, F.T. Hubb. \& C. Schweinf) Hágsater ** & $\mathrm{E}$ & 126 & 0 & 126 \\
\hline Epidendrum tortipetalum Scheeren $* *$ & $\mathrm{E}$ & 5 & 0 & 5 \\
\hline Erycina hyalinobulbon (La Llave \& Lex.) N.H. Williams \& M.W. Chase ** & $\mathrm{E}$ & 53 & 68 & 121 \\
\hline Govenia capitata Lindl. ** & $\mathrm{T}$ & 17 & 26 & 43 \\
\hline Govenia superba (La Llave \& Lex.) Lindl. & $\mathrm{T}$ & 12 & 0 & 12 \\
\hline Hexalectris grandiflora (A. Rich. \& Galeotti) L.O. Williams ** & $\mathrm{T}$ & 21 & 0 & 21 \\
\hline Homalopetalum pachyphyllum (L.O. Williams) Dressler ** & $\mathrm{E}$ & 0 & 2 & 2 \\
\hline Isochilus oaxacanus Salazar \& Soto Arenas * & $\mathrm{R}$ & 14 & 5 & 19 \\
\hline Laelia albida Bateman ex Lindl. ** & $\mathrm{E}$ & 0 & 14 & 14 \\
\hline Laelia furfuracea Lindl. *, ++ & $\mathrm{E}$ & 1 & 136 & 137 \\
\hline Malaxis elliptica A. Rich. \& Galeotti ** & $\mathrm{T}$ & 0 & 24 & 24 \\
\hline Malaxis soulei L.O. Williams & $\mathrm{T}$ & 0 & 1 & 1 \\
\hline Malaxis thlaspiformis A. Rich. \& Galeotti & $\mathrm{T}$ & 51 & 22 & 73 \\
\hline Maxillaria cucullata Lindl. & $\mathrm{R}$ & 114 & 10 & 124 \\
\hline Microepidendrum subulatifolium (A. Rich. \& Galeotti) W.E. Higgins ** & $\mathrm{E}$ & 21 & 0 & 21 \\
\hline Oncidium brachyandrum Lindl. ** & $\mathrm{E}$ & 14 & 0 & 14 \\
\hline Oncidium geertianum C. Morren & $\mathrm{E}$ & 4 & 7 & 11 \\
\hline Oncidium graminifolium Lindl. & $\mathrm{T}$ & 69 & 10 & 79 \\
\hline
\end{tabular}




\begin{tabular}{|c|c|c|c|c|}
\hline \multirow{2}{*}{$\begin{array}{r}\text { Subfamily } \\
\text { Species }\end{array}$} & \multirow{2}{*}{ GF } & \multicolumn{2}{|c|}{ Season } & \multirow{2}{*}{ Total } \\
\hline & & $\mathbf{D}$ & $\mathbf{R}$ & \\
\hline Oncidium reflexum Lindl. **, ++ & $\mathrm{E}$ & 72 & 2 & 74 \\
\hline Prosthechea hastata (Lindl.) W.E. Higgins ** & $\mathrm{E}$ & 1 & 0 & 1 \\
\hline Prosthechea karwinskii (Mart.) Soto Arenas \& Salazar **,+ & $\mathrm{E}$ & 33 & 2 & 35 \\
\hline Prosthechea michuacana (La Llave \& Lex.) W.E. Higgins ** & $\mathrm{T}, \mathrm{E}$ & 212 & 3 & 215 \\
\hline Prosthechea pterocarpa (Lind1.) W.E. Higgins ** & $\mathrm{T}$ & 122 & 14 & 136 \\
\hline Prosthechea semiaperta (Hágsater) W.E. Higgins ** & $\mathrm{R}, \mathrm{E}$ & 21 & 0 & 21 \\
\hline Prosthechea varicosa (Bateman) W.E. Higgins & $\mathrm{T}, \mathrm{E}$ & 24 & 36 & 60 \\
\hline Rhynchostele aptera (La Llave \& Lex.) Soto Arenas \& Salazar ** & $\mathrm{E}$ & 20 & 0 & 20 \\
\hline Rhynchostele cervantesii subsp. membranacea (Lindl.) Soto Arenas \& Salazar *,+ & $\mathrm{E}$ & 77 & 8 & 85 \\
\hline Rhynchostele maculata (La Llave \& Lex.) Soto Arenas \& Salazar & $\mathrm{E}$ & 92 & 0 & 92 \\
\hline Stelis emarginata (Lindl.) Soto Arenas \& Solano ** & $\mathrm{E}$ & 30 & 0 & 30 \\
\hline Stelis sotoarenasii Solano ** & $\mathrm{R}$ & 26 & 0 & 26 \\
\hline Stelis veracrucensis Solano ** & $\mathrm{R}$ & 0 & 463 & 463 \\
\hline \multicolumn{5}{|l|}{ Orchidoideae } \\
\hline Aulosepalum pyramidale (Lind1.) M.A. Dix \& M.W. Dix ** & $\mathrm{T}$ & 3 & 0 & 3 \\
\hline Cranichis cochleata Dressler** & $\mathrm{T}$ & 0 & 2 & 2 \\
\hline Cranichis subumbellata A. Rich. \& Galeotti, Ann. ** & $\mathrm{T}$ & 0 & 274 & 274 \\
\hline Cyclopogon C. Presl. sp. 1 & $\mathrm{R}$ & 20 & 7 & 27 \\
\hline Cyclopogon C. Presl. sp. 2 & $\mathrm{R}$ & 28 & 4 & 32 \\
\hline Deiregyne eriophora (B.L. Rob. \& Greenm.) Garay ** & $\mathrm{T}, \mathrm{E}$ & 684 & 0 & 684 \\
\hline Deiregyne pseudopyramidalis (L.O. Williams) Garay & $\mathrm{T}$ & 91 & 0 & 91 \\
\hline Deiregyne rhombilabia Garay ** & $\mathrm{T}$ & 11 & 0 & 11 \\
\hline Dichromanthus aurantiacus (La Llave \& Lex.) Salazar \& Soto Arenas ** & $\mathrm{T}$ & 0 & 31 & 31 \\
\hline Dichromanthus cinnabarinus (La Llave \& Lex.) Garay ** & $\mathrm{T}$ & 0 & 5 & 5 \\
\hline Funkiella nutantiflora (Schltr.) Salazar \& Soto Arenas & $\mathrm{E}$ & 4 & 0 & 4 \\
\hline Funkiella parasitica (A. Rich. \& Galeotti) Salazar \& Soto Arenas & $\mathrm{E}$ & 5 & 0 & 5 \\
\hline Galeoglossum tubulosum (Lindl.) Salazar \& Soto Arenas & $\mathrm{T}$ & 5 & 2 & 7 \\
\hline Goodyera striata Rchb. f. & $\mathrm{T}$ & 0 & 206 & 206 \\
\hline Greenwoodiella micrantha var. micrantha & $\mathrm{E}$ & 1 & 0 & 1 \\
\hline Habenaria aff. rosulifolia Espejo \& López-Ferr. & $\mathrm{T}$ & 0 & 1 & 1 \\
\hline Habenaria ibarrae R. González ** & $\mathrm{T}$ & 0 & 29 & 29 \\
\hline Habenaria zamudioana R. González ** & $\mathrm{T}$ & 0 & 4 & 4 \\
\hline Mesadenus polyanthus Schltr. ** & $\mathrm{R}$ & 4 & 0 & 4 \\
\hline Platanthera brevifolia (Greene) Senghas ** & $\mathrm{T}$ & 0 & 12 & 12 \\
\hline Platanthera limosa Lindl. ** & $\mathrm{T}$ & 0 & 1 & 1 \\
\hline Ponthieva mexicana (A. Rich. \& Galeotti) Salazar & $\mathrm{T}, \mathrm{R}$ & 0 & 35 & 35 \\
\hline Sarcoglottis schaffneri Ames ** & $\mathrm{T}$ & 11 & 0 & 11 \\
\hline Schiedeella transversalis (A. Rich. \& Galeotti) Schltr. & $\mathrm{R}$ & 2 & 0 & 2 \\
\hline Svenkoeltzia congestiflora (L.O. Williams) Burns-Bal. & $\mathrm{R}$ & 10 & 0 & 10 \\
\hline Total & & 2,460 & 2,473 & 4,933 \\
\hline
\end{tabular}



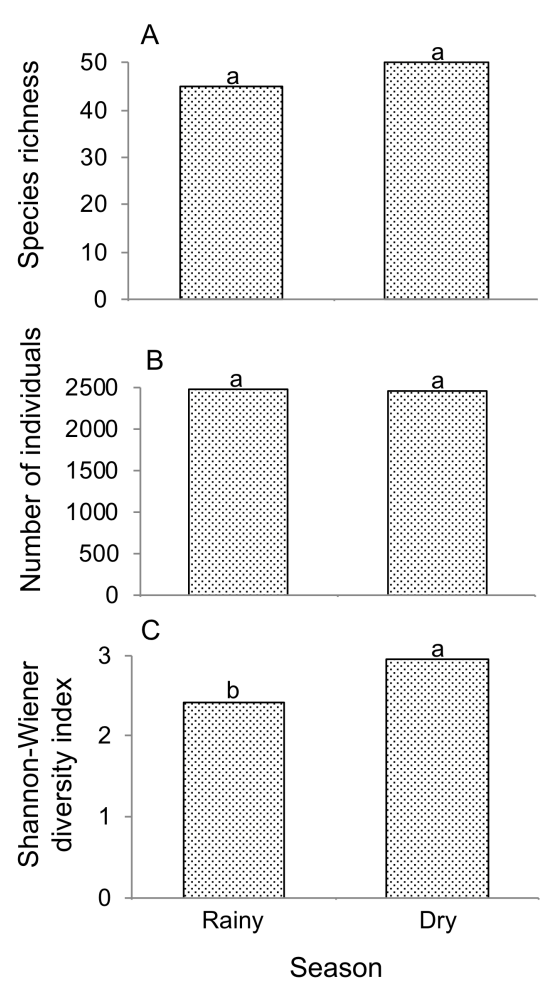

Figure 2. Seasonal variation on different diversity parameters of the community of flowering orchids at the locality of study. A) Species richness, B) abundance, C) Shannon-Wiener diversity index. Different letters within each graph indicate significant differences between seasons.

\section{Discussion}

Our results showed that the community of orchids at the locality of study is constituted by 74 species from 39 genera. The species richness found in the present study corresponds to $5.87 \%$ of the total number of orchid species recorded in Mexico, as well as to $9.68 \%$ of that in the Oaxaca state (Mittermeier \& Mittermeier 1992, Cribb et al. 2003, García-Mendoza 2004, Hágsater et al. 2005, SolanoGómez et al. 2007, 2013, 2016, Villaseñor 2016). Among the species identified, Habenaria ibarrae R. González (Orchidoideae) represents a new record for the state of Oaxaca. Seven species, Anathallis oblanceolata, Barkeria melanocaulum, Epidendrum costatum, E. juergensenii, Isochilus oaxacanus, Laelia furfuracea, and Rhynchostele cervantesii subsp. membranacea (Epidendroideae) are endemic to that Mexican state (Soto-Arenas \& Salazar 2004, Solano-Gómez et al. 2008, Espejo-Serna 2012). In addition, $59.5 \%$ of the rest of the species recorded are endemic to Mexico (Enciclovida 2019). Further, Anathallis oblanceolata, Barkeria melanocaulon, Prosthechea karwinskii (Mart.) Soto Arenas \& Salazar, and Rhynchostele cervantesii subsp. membranacea (Epidendroideae) are listed as "threatened", whereas Laelia furfuracea and Oncidium reflexum Lindl. are subject to special protection according with the NOM-059 (SEMARNAT $2010 \mathrm{a}, \underline{\mathrm{b}}$ ).

Out of the 74 species recorded, 45 were previously registered in the temperate forest of Ixtlán de Juárez (SotoArenas \& Salazar 2004, González-Tamayo \& HernándezHernández 2010, Santiago 2018), a nearby community located within the Sierra Norte of Oaxaca, at around $7.3 \mathrm{~km}$ from Santa Catarina Lachatao. In contrast, 29 of the species found in the present study have not been previously recorded at Ixtlán de Juárez (Santiago 2018). This difference might be attributed to the forest management implemented at each locality. In Ixtlán de Juárez one of the main economic activities is the forestry (Morales-Cruz 2009); whereas in Lachatao, forest management is carried out by the community, following the government structure of customs and traditions (Rojas-Serrano \& MartínezCorona 2017). Moreover, inhabitants of this locality acknowledge the importance of conserving their forest to assure the maintenance of diverse ecosystem services (Rojas-Serrano \& Martínez-Corona 2017).

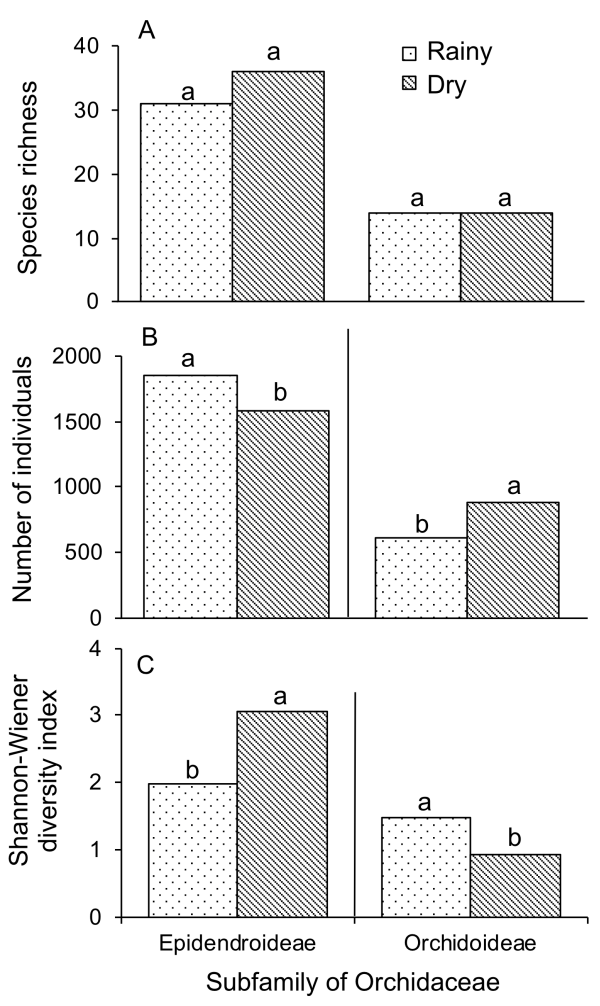

Figure 3. Seasonal variation on species richness (A), abundance (B) and diversity (C) of flowering orchids from the subfamilies Epidendroideae and Orchidoideae recorded in a temperate forest at Santa Catarina Lachatao, Oaxaca. Different letters indicate significant differences between seasons within a subfamily. 


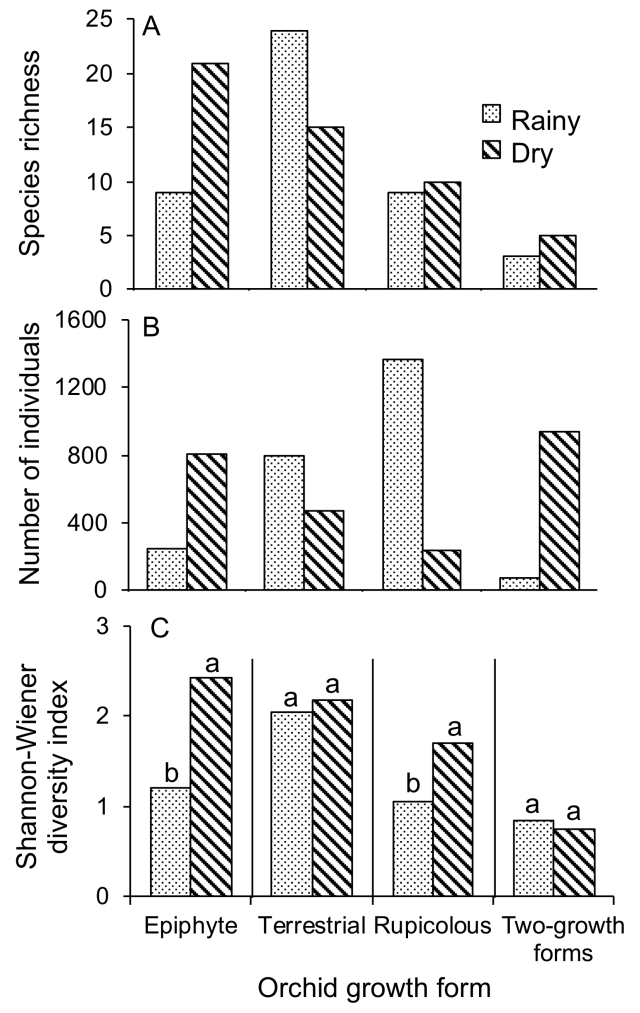

Figure 4. Seasonal variation on species richness (A), abundance (B) and diversity (C) of flowering orchids with different growth form in a temperate forest in Santa Catarina Lachatao, Oaxaca. Different letters indicate significant differences between seasons in the diversity index of flowering orchids within a growth form.

Epidendroideae is the dominant subfamily within Orchidaceae, containing around $80 \%$ of the orchid species known (Cribb et al. 2003, Hágsater et al. 2005). Therefore, it is not surprising that it was also the dominant subfamily at the locality of study ( 49 species, $66 \%$ ); such as it has been recorded in numerous studies (Noguera-Savelli et al. 2015, Nurfadilah 2015, Rewicz et al. 2015, Zhang et al. 2015, Batke et al. 2016, Solano-Gómez et al. 2016, CastilloHernández \& Flores-Olvera 2017, González-Aguilar \& Burelo-Ramos 2017, Meave et al. 2017, Tejeda-Sartorius \& Téllez-Velasco 2017), including some conducted within the state of Oaxaca (Soto-Arenas \& Salazar 2004, Hágsater et al. 2005), and at localities with temperate forests (CerrosTlatilpa \& Espejo-Serna 1998, Luna-Rosales et al. 2007, Huang et al. 2008, Calatayud 2005, Rewicz et al. 2015, Santiago 2018). Likewise, our results showed that at the locality of study, terrestrial orchids had the greatest species richness (32 species), followed by epiphytes (24 species). Similar results were documented by Santiago (2018). However, Calatayud (2005) recorded a strong dominance of epiphytes in a temperate forest dominated by species of Podocarpus. The slightly higher species richness of terrestrial compared with epiphyte orchids found in the present study, might be explained by the dominance of Pinus at the locality of study (UMAFOR 2007), since terrestrial orchids tend to be more numerous in forests dominated by conifers from that genus (Hágsater et al. 2005).

Diverse authors have acknowledged the relative importance of environmental factors, such as atmospheric and microenvironmental humidity for plants with different life form (Gentry \& Dodson 1987, Hietz 1999, Moser et al. 2005, Wang et al. 2009, Werner \& Gradstein 2009). For instance, it has been documented that terrestrial orchids have a strong dependence from the atmospheric humidity, whereas rupicolous and epiphytes are more affected by the microenvironmental conditions provided by lichens and mosses growing with them (Bhattarai \& Vetaas 2003, Hágsater et al. 2005, Swarts \& Dixon 2009b, Souza-Rocha \& Waechter 2010, Damian 2013). Therefore, the relative importance of atmospheric and microenvironmental humidity for orchids from each growth form might explain the differences detected in flowering for the whole community of orchids as well as per growth form between seasons. However, the environmental conditions preferred by orchids with different growth form do not seem to explain the differences in abundance found within each subfamily. Our results showed that the epiphyte dominated Epidendroideae subfamily had a higher abundance of flowering individuals during the rainy season and that the terrestrial dominated Orchidoideae subfamily had more flowering individuals during the dry one. These results might be explained by the super-high number of flowering individuals of the rupicolous Anathallis oblanceolata (Epidendroideae) and the predominantly terrestrial Deiregyne eriophora (Orchidoideae) during the rainy and dry seasons, respectively. This suggests that the abundance of flowering individuals of these species is determined by other factors such as the availability of pollinators, light availability, competition with the surrounding vegetation, presence/absence of well-developed water storage organs, and plant size/age (Heywood 1954, Mehrhoff 1989, Sahagún-Godinez 1996, Hágsater et al. 2005, Janecková et al. 2006, Swarts \& Dixon 2009a, De la Rosa-Manzano et al. 2014, Š́tívková et al. 2018).

In conclusion, our results showed that the locality of Santa Catarina Lachatao hosts a great diversity and endemisms of orchids. Moreover, most parameters of the flowering community of orchids varied according with seasonality, which might be explained by the particular conditions required by each group of orchids to flower. The relatively low similarity in the composition of flowering species between seasons suggests that the community is highly diverse, and that flowering might be determined by the fulfilment of particular requirements needed by each 
subgroup of orchids. Even when some of the species found, such as Artorima erubescens (Lindl.) Dressler \& G.E. Pollard and Rhynchostele maculata (La Llave \& Lex.) Soto Arenas \& Salazar are associated with fragmented habitats (Hernández-Pérez \& Solano 2015), the richness found, as well as the endemism and endangered species suggest that the locality is still a good reservoir of orchids. Strategies to protect and manage the forest are needed in order to assure its conservation as well as all the diversity within it.

\section{Acknowledgments}

The authors are very thankful with the local people at Santa Catarina Lachatao in the State of Oaxaca, for allowing us to conduct this study. We are especially grateful with Juan Santiago-Hernández, Verónica Hernández, Rosalía Carrasco-Gómez, and Óscar Martínez-Galindo for logistic support. Arturo Casasola, Juan Santiago-Hernández, Samantha de los Santos, Sandra Aguilar, Itzel Castillo, Abraham Mendoza, Maria Vazquez, Nayeli Diyarza, Jonatan Varela, Antonio Munguía, Jonathan Arce, and Osvaldo Jiménez provided field assistance. Gerardo Salazar and Rolando Jiménez-Machorro were very supportive with species identification. This study was funded with a grant awarded to D.M. F.-C. from Vicerrectoría de Investigación y Estudios de Posgrado of the Benemérita Universidad Autónoma de Puebla (No. 100498433-VIEP2018).

\section{Literature cited}

Allesh P, Kuriakose G, Chandrashekara K. 2011. Epiphytic orchid diversity in farmer-managed Soppinabetta forestas of Western Ghats: implications for conservation. Current Science 10: 1337-1346.

Batke S, Cascánte-Marín A, Kelly D. 2016. Epiphytes in Honduras: a geographical analysis of the vascular epiphyte flora and its floristic affinities to other Central American countries. Tropical Ecology 57: 663-675.

Bhattarai KR, Vetaas OR. 2003. Variation in plant species richness of different life forms along a subtropical elevation gradient in the Himalayas, East Nepal. Global Ecology and Biogeography 12: 327-340. DOI: https:// doi.org/10.1046/j.1466-822X.2003.00044.x

Calatayud G. 2005. Diversidad de la familia Orchidaceae en los bosques montanos de San Ignacio (Cajamarca, Perú). Revista Peruana de Biología 12: 309-316. DOI: https:// doi.org/10.15381/rpb.v12i2.2404

Castillo-Hernández LA, Flores-Olvera H. 2017. Floristic composition of the cloud forest of the Bicentenario Reserve, Zongolica, Veracruz, Mexico. Botanical Sciences 95: 1-25. DOI: https://doi.org/10.17129/botsc $\underline{\mathrm{i} .1223}$
Cerros-Tlatilpa R, Espejo-Serna A. 1998. Contribución al estudio florístico de los cerros El Sombrerito y Las Mariposas (Zoapapalotl) en el Municipio de Tlayacapan, Morelos, México. Polibotánica 8: 29-46.

Chase MW, Cameron KM, Barrett RL, Freudenstein JV. 2003. DNA data and Orchidaceae systematics: a new phylogenetic classification. In: Dixon KW, Kell SP, Barrett RL, Cribb PJ, eds. Orchid Conservation. Kota Kinabalu, Sabah, Malaysia: Natural History Publications, pp. 69-89. ISBN: 983-812-078-2.

Cox LD, Ruíz JYS, Pérez EA. 2016. Diversidad y uso de las orquídeas. Bioagrociencias 9: 1-6.

Cribb PJ, Kell SP, Dixon KW, Barrett RL. 2003. Orchid conservation: a global perspective. In: Dixon KW, Kell SP, Barrett RL, Cribb PJ, eds. Orchid Conservation. Kota Kinabalu, Sabah, Malaysia: Natural History Publications, pp. 1-2. ISBN: 983-812-078-2

Damian A. 2013. Diversidad y distribución altitudinal de especies terrestres de la familia Orchidaceae en un bosque montano al interior del Parque Nacional Yanachaga Chemillen (Pasco, Perú). Arnaldoa 20: 103-116.

Damian A. 2015. Distribución vertical y horizontal de la familia Orchidaceae en tres tipos de bosques en el sector Paujil, al interior del Parque Nacional Yanachaga Chemillen (Pasco-Perú). Revista Q'euña 6: 67-68.

De la Rosa-Manzano E, Andrade JL, Zotz G, Reyes-García C. 2014. Epiphytic orchids in tropical dry forests of Yucatan, Mexico. Species occurrence, abundance and correlations with host tree characteristics and environmental conditions. Flora 209: 100-109. DOI: https://doi.org/10.1016/j.flora.2013.12.002

Enciclovida. 2019. CONABIO. Disponible en: http:// www.enciclovida.mx (accessed November 13, 2019).

Espejo-Serna A, García-Cruz J, López-Ferrari AR, Jiménez-Machorro R, Sánchez-Saldaña L. 2002. Orquideas del Estado de Morelos. Mexico City: Jiménez, ISBN: 0300-3107

Espejo-Serna A, López-Ferrari AR, Jiménez R, Sánchez L. 2005. Las orquídeas de los cafetales en México: una opción para el uso sostenible de ecosistemas tropicales. Revista de Biología Tropical 53: 1-9.

Espejo-Serna A. 2012. El endemismo en las Liliopsida mexicanas. Acta Botanica Mexicana 100: 195-257. DOI: https://doi.org/10.21829/abm100.2012.36

Focho DA, Fonge BA, Fongod AGN, Essomo SE. 2010. A study of the distribution and diversity of the Family Orchidaceae on some selected lava flows of Mount Cameroon. African Journal of Environmental Science and Technology 4: 263-273.

García-González A, Pérez-Márquez R. 2011. La comunidad orquideológica en la Reserva de la biosfera Sierra del 
Rosario, Cuba. Revista de Biología Tropical 59: 1805-1812.

García-Mendoza AJ. 2004. Integración del conocimiento florístico del estado. In: García-Mendoza AJ, Ordóñez MJ, Briones-Salas M, eds. Biodiversidad de Oaxaca. Mexico City: Instituto de Biología, Universidad Nacional Autónoma de México, Fondo Oaxaqueño para la Conservación de la Naturaleza, World Wildlife Fundation, pp. 305-325. ISBN: 970-32-2045-2; 9789703220458

Gentry AH, Dodson CH. 1987. Diversity and biogeography of neotropical vascular epiphytes. Annals of the Missouri Botanical Garden 74: 205-233. DOI: https://doi.org/ $\underline{10.2307 / 2399395}$

Gogoi K, Borah RL, Sharma GC, Yonzone R. 2012a. Present status of orchid species diversity resources and distribution in Dibrugarh District of Assam of North East India. International Journal of Modern Botany 2: 47-67. DOI: https://doi.org/10.5923/j.ijmb.20120202.02

Gogoi K, Borah RL, Das R, Yonzone R. 2012b. Present status of orchid species diversity resources of Joypur Reserve forest of Dibrugarh District (Assam) of North East India. International Journal of Modern Botany 2: 47-67. DOI: https://doi.org/10.5923/j.ijmb.20120203.03

González-Aguilar MA, Burelo-Ramos CM. 2017. Adiciones a la orquideoflora de Tabasco, México. Acta Botanica Mexicana 121: 161-167. DOI: https://doi.org/ $\underline{10.21829 / \mathrm{abm} 121.2017 .1292}$

González-Tamayo JR, Hernández-Hernández L. 2010. Las orquídeas del occidente de México. Vol. 1. Guadalajara: Consejo Estatal de Ciencia y Tecnología de Jalisco. ISBN: 9786070040412

González-Ríos A. 2011. Oaxaca 2011: Un Diagnóstico Breve. Oaxaca: Grupo Mesófilo, A.C. https://studylib. es/doc/7858136/oaxaca-2011--un-diagn\%C3\%B3stico-br eve (accessed October 20, 2019).

Gutiérrez NY. 2014. Diversidad de epifitas vasculares en bosques perturbados de diferentes edades en el valle del rio San Francisco al sur de Ecuador. BSc Thesis, Universidad Nacional Jorge Basadre de GrohmannTacna.

Hágsater E, Soto-Arenas MA, Salazar-Chávez GA, Jiménez-Machorro R, López-Rosas MA, Dressler RL. 2005. Las Orquídeas de México. Mexico City: Instituto Chinoín. ISBN: 9687889071; 9789687889078

Hammer Ø, Harper DAT, Ryan PD. 2001. PAST: Paleontological Statistics Software package for education and data analysis. Palaeontologia Electronica 4: 1-9.

Hernández-Pérez E, Solano E. 2015. Effects of habitat fragmentation on the diversity of epiphytic orchids from a montane forest of Southern Mexico. Journal of
Tropical Ecology 31: 103-115. DOI: https://doi.org/ $\underline{10.1017 / \mathrm{S} 0266467414000662}$

Heywood VH. 1954. El concepto de asociación en las comunidades rupícolas. Anales del Jardín Botánico de Madrid 11: 463-481.

Hietz P. 1999. Diversity and conservation of epiphytes in a changing environment. Pure and Applied Chemistry 70: 2114-2125.

Huang BQ, Yang XQ, Yu FH, Luo YB, Tai YD. 2008. Surprisingly high orchid diversity in travertine and forest areas in the Huanglong valley, China, and implications for conservation. Biodiversity and Conservation 17: 2773-2786. DOI: https://doi.org/10.1007/s10531-0079291-2

INEGI [Instituto Nacional de Estadística y Geografía]. 2005. Prontuario de información geográfica municipal de los Estados Unidos Mexicanos. Santa Catarina Lachatao, Oaxaca. Clave geoestadística 20365. https://www.inegi. org.mx/contenidos/app/mexicocifras/datos_geograficos/2 0/20365.pdf (accessed June 20, 2019)

Janecková P, Wotavová K, Schödelbauerová I, Jersáková J, Kindlmann P. 2006. Relative effects of management and environmental conditions on performance and survival of populations of a terrestrial orchid, Dactylorhiza majalis. Biological Conservation 129: 40-49. DOI: https://doi. org/10.1016/j.biocon.2005.09.045

Luna-Rosales BS, Barba-Álvarez A, Romero-Tirado R, Pérez-Toledano E, Perea-Morales O, Padrón-Hernández S, Sierra-Jiménez H, De la Cruz R, Jardón-Sánchez D. 2007. Diversidad de orquídeas en el "Parque Nacional Iztaccihuatl-Popocatépetl” (México) y sus áreas de influencia. Lankesteriana International Journal on Orchidology 7: 56-59.

Meave JA, Rincón-Gutiérrez A, Ibarra-Manríquez G, Gallardo-Hernández C, Romero-Romero MA. 2017. Checklist of the vascular flora of a portion of the hyperhumid region of La Chinantla, Northern Oaxaca Range, Mexico. Botanical Sciences 95: 722-759. DOI: https:// doi.org/10.17129/botsci.1812

Mejía-Rosero H, Pino-Benitez N. 2009. Diversidad de orquídeas epífitas en un bosque húmedo tropical (Bh-T) del Departamento del Chocó, Colombia. Acta Biológica Colombiana 15: 37-46.

Mehrhoff LA. 1989. Reproductive vigor and environmental factors in populations of an endangered North American orchid, Isotria medeoloides (Pursh) Rafinesque. Biological Conservation 47: 281-296. DOI: https://doi. org/10.1016/0006-3207(89)90071-2

Mittermeier RA, Mittermeier C. 1992. La importancia de la diversidad biológica en México. In: Sarukán J, Dirzo R, eds. México Ante los Retos de la Biodiversidad. Mexico City: Comisión Nacional para el Conocimiento y Uso de 
Muñoz Hernández et al. / Botanical Sciences 98(3): 573-584. 2020

la Biodiversidad, pp. 3-14. ISBN: 9683624545; 9789683624543

Morales-Cruz JC. 2009. Diagnóstico y plan de desarrollo municipal de: Ixtlán de Juárez. Oaxaca: SAGARPA, Secretaría de Desarrollo Rural de Oaxaca. https://www. finanzasoaxaca.gob.mx/pdf/inversion_publica/pmds/08 10/042.pdf (accessed October 3, 2019).

Morales J. 2012. Diversidad y conservación de orquídeas en plantaciones de cacao del Sureste de México. MSc Thesis, Instituto de Ecología, AC.

Moser D, Dullinger S, Englisch T, Nicklfeld H, Plutzar C, Sauberer N, Zechmeister HG, Grabherr G. 2005. Environmental determinants of vascular plant species richness in the Austrian Alps. Journal of Biogeography 32: 1117-1127. DOI: https://doi.org/10.1111/j.1365-2699. 2005.01265.x

Noguera-Savelli E, Cetzal-Ix W. 2014. Revisión e integración del conocimiento de la Orchidaceae de Tabasco, México. Botanical Sciences 92: 519-540. DOI: https://doi.org/10.17129/botsci.117

Noguera-Savelli E, Cetzal-Ix W, Burguillos M, Tillett J, Jiménez E, Kamur S. 2015. The floristic composition and biodiversity of Orchidaceae in the Guatopo National Park, Venezuela and the urgent need for the conservation of the parks biodiversity. Journal of the Torrey Botanical Society 142: 63-77. DOI: https://doi.org/10.3159/TORR EY-D-14-00049.1

SEMARNAT [Secretaría del Medio Ambiente y Recursos Naturales]. 2010a. Norma Oficial Mexicana NOM-059SEMARNAT-2010, Protección ambiental - Especies nativas de México de flora y fauna silvestres - Categorías de riesgo y especificaciones para su inclusión, exclusión o cambio - Lista de especies en riesgo. Diario Oficial de la Federación. 2da Sección, 30 de diciembre de 2010.

SEMARNAT. 2010b -Modificación. Norma Oficial Mexicana NOM-059-SEMARNAT-2010, - Especies nativas de México de flora y fauna silvestres - Categorías de riesgo y especificaciones para su inclusión, exclusión o cambio - Lista de especies en riesgo. Diario Oficial de la Federación, 3ra Edición. México. (Modificado 14/11/2019).

Nurfadilah S. 2015. Diversity of epiphytic orchids and host trees (phorophytes) in secondary forest of Coban Trisula, Malang Regency, East Java, Indonesia. Biotropica 22: 120-128. DOI: http://dx.doi.org/10.11598/btb.2015.22.2. $\underline{450}$

Pridgeon AM, Philips J, Cribb J, Chese M, Rasmussen F. 1999. Genera Orchidacearum. Vol. 1. Oxford: Oxford University. ISBN: 0198505132; 978-0198505136

Rewicz A, Zielinska KM, Kiedzynski M, Kucharsqui L. 2015. Orchidaceae in the anthropogenic landscape of Central Poland: diversity, extinction and conservation perspectives. Archives of Biological Sciences 67: 119-130. DOI: https://doi.org/10.2298/ABS140428014R

Roberts D, Dixon K. 2008. Orchids. Current Biology 18: R325-R329. DOI: https://doi.org/10.1016/j.cub.2008.02. $\underline{026}$

Rojas-Serrano C, Martínez-Corona B. 2017. Transformations and continuities in the management and conception of the forest and gender relations in Santa Catarina Lachatao, Oaxaca. Agricultura, Sociedad y Desarrollo 14: 451-478.

Rzedowski J. 1992. Diversidad del universo vegetal de México: perspectivas de un conocimiento sólido. In: Sarukhán J, Dirzo R, comp. México Ante los Retos de la Biodiversidad. Mexico City: Comisión Nacional para el Conocimiento y uso de la Biodiversidad (CONABIO), pp. 251-258. ISBN: 9683624545 ; 9789683624543

Rzedowski J. 1996. Análisis preliminar de la flora vascular de los bosques mesófilos de montaña de México. Acta Botanica Mexicana 35: 24-44. DOI: https://doi.org/10. 21829/abm35.1996.955

Sahagún-Godinez E. 1996. Trends in the phenology of flowering in the Orchidaceae of Western Mexico. Biotropica 28: 130-136. DOI: https://doi.org/10.2307/ $\underline{2388778}$

Santa NN, García T, Gómez GD. 2009. Estructura y composición de la comunidad de orquídeas en dos zonas de la Reserva Natural "La Montaña del Ocaso" Quimbaya-Quindío. Revista de Investigación de la Universidad del Quindio 19:122-134.

Santiago LR. 2018. Contribución al conocimiento de la familia Orchidaceae Juss. de los bosques templados de Ixtlán de Juárez. BSc Thesis, Universidad de la Sierra Juárez.

Solano-Gómez R, Alonso-Hernández N, Rosado-Ferrer K, Aguilar-Hernández MA, García R. 2008. Diversidad, distribución y estrategias para la conservación de las Pleurothallidinae (Orchidaceae) en Oaxaca. Boletin de la Sociedad Botánica de México 82: 41-52. DOI: https:// doi.org/10.17129/botsci.1780

Solano-Gómez R, Bello-López R, Vásquez-Martínez A. 2007. Listado de las orquídeas de la región de Juquila, Oaxaca, México. Naturaleza y Desarrollo 5: 5-14.

Solano-Gómez R, Martínez-Ovando E, Martínez-Feria A, Gutiérrez-Caballero JA. 2016. New records in the Orchidaceae family from Oaxaca, Mexico. Revista Mexicana de Biodiversidad 87: 1348-1351. DOI: https:// doi.org/10.1016/j.rmb.2016.09.012

Solano-Gómez R, Rubio-Espinosa M, Lagunez-Rivera L, Herrera-Arenas O. 2013. Orquídeas de la Sierra Mixe de Oaxaca. In: Briones-Salas M, Manzanero-Medina G, González-Pérez G, eds. Estudios en Zonas Áridas de Oaxaca. Homenaje al Dr. Alejandro Flores Martínez. Oaxaca: CIIDIR Unidad Oaxaca, Instituto Politécnico Nacional, pp. 57-73. ISBN: 9786079305055; 6079305054 . 
Soto-Arenas MA, Solano-Gómez R, Hágsater E. 2007a. Risk of extinction and patterns of diversity loss in mexican orchids. Lankesteriana International Journal on Orchidology 7: 114-121.

Soto-Arenas MA, Hágsater E, Jiménez-Machorro R, Salazar-Chávez GA, Solano-Gómez R, Flores-González R, Ruiz-Contreras I. 2007b. Las orquídeas de México. Catálogo Digital. Mexico City: Instituto Chinoín, AC. DVD.

Soto-Arenas MA, Salazar GA. 2004. Orquídeas. In: García Mendoza AJ, Ordóñez MJ, Briones-Salas M, eds. Biodiversidad de Oaxaca. Mexico City: Instituto de Biología, UNAM, Fondo Oaxaqueño para la Conservación de la Naturaleza, World Wildlife Fundation, pp. 271-295. ISBN: 9703220452; 9789703220458

Souza-Rocha F, Waechter JL. 2010. Ecological distribution of terrestrial orchids in a south Brazilian Atlantic region. Nordic Journal of Botany 28: 112-118. DOI: https:// doi.org/10.1111/j.1756-1051.2009.00500.x

Stevens PF. 2001-onwards. Angiosperm Phylogeny Website. Version 14, July 2017 [and more or less continuously updated since]. <http://www.mobot.org/ MOBOT/research/APweb/> (accessed September 17, 2019).

Štívková Z, Kosánová K, Romportl D, Kindlmann P. 2018. Determinants of orchid occurrence: a Czech example. In: Bülent Ş, ed. Selected Studies in Biodiversity. IntechOpen. pp 133-155. ISBN: 978-1-78923-233-2. DOI: https://doi.org/10.5772/66032

Susan-Tepetlan TM, Velázques-Rosas N, Krömer T. 2015. Cambios en las características funcionales de epífitas vasculares de bosque mesófilo de montaña y vegetación secundaria en la región central de Veracruz, México. Botanical Sciences 93: 153-163. DOI: http://dx.doi.org/ 10.17129/botsci.228

Swarts ND, Dixon KW. 2009a. Perspectives on orchid conservation in botanic gardens. Trends in Plant Science 14: 590-598. DOI: https://doi.org/10.1016/j.tplants.2009. 07.008

Associated Editor: Hilda Flores Olvera

Author contributions: All authors participated in the design of the project, specimen collection, and writing of the manuscript. AEMH and DMFC authors conducted the analysis of results.
Swarts ND, Dixon KW. 2009b. Terrestrial orchid conservation in the age of extinction. Annals of Botany 104: 543-556. DOI: https://doi.org/10.1093/aob/mcp025

Tejeda-Sartorius O, Tellez-Velasco MAA. 2017. Riqueza de la Familia Orchidaceae en un bosque mesófilo de montaña en Chocamán, Veracruz, Méxio. Acta Botanica Mexicana 121: 139-149. DOI: http://dx.doi.org/10.218 29/abm121.2017.1177

Téllez-Velasco MAA. 2011. Diagnóstico de la Familia Orchidaceae en México. Texcoco, Estado de México: Universidad Autónoma de Chapingo. ISBN: 978-607-12-0206-2

UMAFOR [Unidad de Manejo Forestal]. 2007. Estudio regional forestal para el fortalecimiento de las unidades de manejo forestal en la Sierra Norte de Oaxaca. México: UMAFOR, <http://www.conafor.gob.mx:8080/documen tos/docs/9/1091ERF_UMAFOR2001.pdf $>$ (accessed June 20, 2019)

Villaseñor JL. 2016. Checklist of the native vascular plants of Mexico. Revista Mexicana de Biodiversidad 87: 559-902. DOI: https://doi.org/10.1016/j.rmb.2016.06.017

Wang X, Fang J, Sander NJ, White PS, Tang Z. 2009. Relative importance of climate vs. local factors in shaping the regional patterns of forest plant richness across northeast China. Ecography 32: 133-142. DOI: https://doi.org/10.1111/j.1600-0587.2008.05507.x

Werner FA, Gradstein SR. 2009. Diversity of dry forest epiphytes along a gradient of human disturbance in the tropical Andes. Journal Vegetation Science 20: 59-68. DOI: https://doi.org/10.1111/j.1654-1103.2009.05286.x

Williams-Linera G, Sosa V, Platas T. 1995. The fate of epiphytic orchids after fragmentation of a Mexican cloud forest. Selbyana 16: 36-40.

Zhang Z, Yan Y, Tian Y, Li J, He J, Tang Z. 2015. Distribution and conservation of orchid species richness in China. Biological Conservation 181: 64-72. DOI: https://doi.org/10.1016/j.biocon.2014.10.026 